\title{
A Reconstruction of the Racist Ideology in Richard Wright's Native Son
}

\author{
Jismulatif, ${ }^{1}$ Dadang Suganda, ${ }^{2}$ Davidescu Cristiana $\mathbf{M}^{3}$ \\ ${ }^{I}$ (Faculty of Humanities, Padjadjaran University, Sumedang, 40132, Indonesia) \\ ${ }^{2}$ (Faculty of Humanities, Padjadjaran University, Sumedang, 40132, Indonesia) \\ ${ }^{3}$ (Faculty of Humanities, Padjadjaran University, Sumedang, 40132, Indonesia)
}

\begin{abstract}
This study aimed to analyze the relation between power and language in Richard Wright's Native Son. Critical Discourse Analysis (CDA) provided analytical tools that could be used to uncover bias in texts. This study used Norman Fairclough's three dimensional CDA framework to analyze a racist ideology in Richard Wright's Native Son. White domination is an effort done by the white people to maintain 'White-Superiority' and 'Black-Inferiority'. In this case many Blacks have problem or difficulties in the aspect of their life. The result shows that through the white's superiority the Blacks were the oppressed people. Being the oppressed people, they were unjustly treated by the white power such as racial prejudice, discrimination, and segregation. Consequently, they had some problems in the aspects of their social lives. they were regarded as inferior creatures, and they do not have equalities in education, employment, law protection or law enforcement, and in the other aspects of socio-cultural life.
\end{abstract}

Key words: language, power, critical discourse analysis, racist discourse

\section{Introduction}

Language is one of the most important things in human being, without language the human being can not communicate, interaction and tell their experience to each other. In this Globalization era the function of language is not only to communicate but already developed as hegemony in social life. Fairclough (1989: 2-4; 1995b:12-15) said that in modern society in this time execution power progressively mount and reached to ideology which is peculiarly launched through language intercession. In this matter is caused language socially and historically action form with social structure. Therefore, language and social structure can be formulated as two parts which cannot be dissociated. Concerning language studies in these days should give attention and interconnected with social structure existing in our society. In this case Fairclough (1992a: 1-2) said that "one is the isolation of language studies from other social sciences, and the domination of linguistics by formalistic and paradigms. Another is the traditional lack of interest in language on the part of other social sciences, and a tendency to see language as transparent: while linguistics data such as interviews are widely used, there has been a tendency to believe that the social content of such data can be read off without attention to the language itself." In discourse analysis, the work of literature is called literature discourse. In general, the character of literature discourse can be seen in the language usage which are aesthetically and imaginative but possibly the content is much the same with fact.

Novel is a literary work that uses language as a tool to convey a message to the reader. Literature has a close relation with the things that happen in the life of a society. In addition, historical and environmental factors also take the important role in establishing a literary work, because the author is a part of society. In this case, the discourse of racism in the novel Native Son shows that the power and ideology of racism of white against blacks.

In the novel Native Son, the unfair treatment between whites and blacks can be seen from the language expressions that appear in the novel. From the language, it can be seen the domination of white people to black people in education, employment, and legal protection. Black people were often treated unfairly by the white race, for example, the blacks were often given a negative or stereotypical concept by white men such as nigger, murderer, fool, black servant, and lazy Negro.

Language of racism in the novel Native Son can dismantle racism practices and social white community in America particularly the domination of the white race against the black race. From the relations between sentences that make up a language discourse, can be traced that the whites had treated the blacks as an inferior race, the whites are superior. Novel is a text that can be seen from any different perspectives. One of them is the critical discourse analysis, which Fairclough stated;

“...to systematically explore often opaque relationships of causality and determination between (a) discursive practices, events and texts, and (b) wider social and cultural structures, relations and 
processes; to investigate how such practices, events and texts arise out of and are ideologically shaped by relation of power and struggles over power" (Fairclough, 1995).

Thus, the novel can be regarded as a manifestation of the relationship between the structure of the text itself as a social and cultural background, through language and ideology. By tracking and analyzing the discourse linguistic expression in the novel Native Son, we would find out how are the relationship between whites and blacks in America in 1930s.

The hatred of the white race against the black race can be seen from the texts of the novel Native Son. It can be seen from the following of example: He knew that black people could not go outside of the Black Belt to rent a flat; they had to live on their side of the "line." No white real estate man would rent a flat to a black man other than in the sections where it had been decided that black people might live." (NS.161).

The discourse above shows the inferiority of the blacks that they cannot afford to live in the same society as the whites. It shows that the whites have the power on the blacks. The discourse shows the domination of white over the blacks. The blacks are often being treated unfairly when they want to use public facilities. This research aims to describe and study the white domination and its effects on African American. White domination is an effort done by the white people to maintain 'White-Superiority' and 'Black-Inferiority'.

\section{Theoretical Framework}

The theories used in this research is the analitycal discourse model by Norman Fairclough (1992b, 1995a, 1998, 2000) which is known as the three dimension model. The definition of the three dimension analytical discourse is in analyzing a discourse, it focuses on three level, of analysis which are (1) text analysis ( micro level). In this level, a text is analyzed linguistically, based on the vocabulary, cohesion and coherence, grammar, transitivity, topic, and modality that refer to racist ideology; (2) analytical discourse based on Discourse practice (meso level) in this level, a text will be analyzed based on the text production, distribution and consumsion of a text; and (3) sociocultural practice (macro level), it means that, the relation of a text will be analyzed out of context.

CDA not only focuses on the linguistic phenomenon but also on the local interpretation which is more like an exploration on how a text works in sociocultural performances, which is the background of the author. Fairclough stated that the sociocultural practice analysis is based on the idea about the social context in the text which influences a literary work. According to Fairclough, there are 3 levels of sociocultural practice which are situational, institutional, and social (Fairclough, 1992a). In this stage, a text seen from a sociocultural perspective of the society, like racism in the novel Native Son. The data of this research is a novel entitled Native Son. This novel is chosen because of several reasons. First, the novel itself is a very famous literary work about racism and was published in America in 1940s. It is about the life experience of black people in America. The author of the novel is black as well who experienced the discrimination. Second, the novel tells us the how the black people discriminated in America in 1930s. Third, it was the first best selling novel written by a black man in America. Fourth, it was published by Harper Perennial Modern Classics, one of the most famous publishers in America, before some other publishers like Radcliffe Publishing Course, Modern Library, Oxford American, and Boston publish the novel.

\section{The Sociocultural of Racism}

Racism as a social system in a society is a manipulation of power by a group of dominant race, in this case, the white people. The dominance of a race is realized in the form of discriminatory practices against minority racial group. The dominance of an ethnic has two dimensions, namely social and cognitive dimensions. The social dimension of the practice of discrimination seen in the daily lives of different ethnic groups, while the cognitive dimension looks at beliefs about a group of ethnic prejudice, stereotypes, and ideology which serves as a motivation to legalize the practice of discrimination against an ethnic. Ideology practice of racism seen in the fields of education, employment, law, and the use of public facilities. As van Dijk (1987) stated. "Racism is a complex system of social inequality in which at least the following components are combined: a) ideologically based social representations of (and about) groups. b) Group members' mental models of concrete ethnic events. c) Everyday discriminatory discourse and other social practices. d) Institutional and organizational structures and activities. e) Power relations between dominant white and ethnic minority groups". Pramoedya Ananta Toer (1998:50), provides a definition of racism as understand that rejecting a community group based on racial differences. As a result, there was a white supremacist which harms people from colored race; McNeilly (1996) stated that racism is a concept that contains a variety of dimensions including prejudice and discrimination against minority groups.

From the analytical discourse of novel Native Son, treatment practices of the ideology of racism against blacks, for example, differential treatment in education, employment, legal, and cultural use of common facilities. The unequal treatment is implemented in the form of discrimination, prejudice and segregation. Black 
people are prohibited to live side by side with the whites. Blacks are considered to come from a different planet to the white race.

The exclusion of the black race has been started the first time since their arrival in America. Their arrival to America is required because the whites need slaves. As a slave, they were employed in the South American plantation area. They were forced to work all day without any regard to their wages and health. This treatment was based on the differences of color, race, and culture of the black race. They were considered very low while the whites are the chosen people.

\section{The Implications of Racism Ideology against Social Context}

The discourse analysis of Native Son texts found the practices of the racism ideology against blacks like different treatments in education, employment, law, the use of public facilities, and culture. Those injustice treatments were realized in the form of discrimination, prejudice, and separation. The blacks were prohibited to live side by side with the white race. The Blacks were considered coming from a different planet to the whites. The ideology of racism from Native Son discourse can be seen from various aspects of social life of the blacks, such as the occurrence of discrimination, segregation, prejudice, and stereotypes in education, employment, legal protection, housing, and the use of public facilities.

\subsection{Educational Aspect}

The ideology of racism in education aspect can be seen from the texts of racism discourse which were contained in the Native Son novel. Bigger Thomas as the central figure in Native Son realized the importance of education for the black race in America, because it was expected that the black race life could be changed into a better one through education. As a result of discrimination against blacks in education, it was hard for them to get a better education. It was strongly felt by Bigger Thomas when he wanted to continue his education to the higher level. The discrimination against blacks in education aspect can be seen from the following quoted texts of Native Son discourse.

(1) The white neighbor decided to limit the amount of education his black neighbor could receive. (NS.5)

If you wasn't black and you had some money and if they'd let you go to that aviation school, you could fly a plane." "I could fly a plane if I had a chance" (NS.20)

I wanted to be an aviator once. But they wouldn't let me go to the school where I was suppose' to learn it. (NS.327)

The quoted discourses (1), (2), and (3) above showed that "Bigger" which is derived from the blacks tells that the blacks were not allowed to continue their education by the white race. Richard Wright who was the author of Native Sons showed that the discrimination among the white and the black races occurred in education aspect. It indicates that the ideology of racism influenced the education of blacks in America, where the blacks were not allowed to attend school with the white people. Besides, the black people were not allowed to continue their school to the higher level of education as recorded in the history of the black community's life in America.

As a result of this racism, the black race was very difficult to get equal rights in education whereas the education was very important for blacks to improve their lives. Education can up lift the level of the blacks into a good status by the white race. The discrimination experienced by the blacks in education aspect didn't only happen in term of prohibition in attending school with whites but also occurred in school segregation, the blacks were only allowed to study with the blacks fellow 'black school' and so was the whites 'white school' .

The similar events were also experienced by Bigger when they wanted to study in the white race school, because of he was black that he was forbidden to go to school there, as shown by the text stated in the discourse of Native Son "They built a big school and then drew a line around it and said that nobody could to it but those who lived within the line. That kept all the colored boys out." (NS.327)

The text above shows the dominance of the white race who distinguished treatment in education aspect between the whites and the blacks, where there was separation between the children of the blacks and the white race children. This different treatment was due to the ideology of racism which developed by the white race in America at that time.

The separation between white and black students had become a habit since the slavery period, and the result of the treatment caused suffering on the black community. Therefore, the black race had to undergo a long struggle to get a better education. The motivation of their struggle was a belief that education is a key to enhance the dignity, social status, and common citizenship.

The discrimination against blacks did not only happen in school segregation, but also in education subsidies, the whites got bigger subsidies than the black race. This injustice treatment occurred mostly in the southern region of the United States. In the 1935-1936 attend southern American States, the subsidies which were received by the blacks were only $\$ 17.4$, while the whites got $\$ 49.30$. It also occurred in the region of 
Mississippi and Georgia where the black children got the education subsidies of $\$ 9$ while the white kids got \$45. The lack of education subsidies and school facilities harmed the blacks so much which resulted in low quality of education obtained by the black race. A striking difference between the white race and the black race in education subsidies caused the black community's education in the region of South America getting far behind comparable to the white community.

\subsection{Employment Aspect}

The racism ideology had an impact on the work of the black race in America, where they got a lowly job while whites get better jobs. As a result of this discrimination in employment aspect, many people who came from the blacks got jobs as slaves and as laborer like maid, gardener, and cooks.

The texts of Native Son discourse show the practice of discrimination against blacks in the employment aspect. Richard Wright's, the writer of Native Son wants to describe the discrimination experienced by bigger as descendants of the black race. It can be seen from the following texts of the discourse.

He had no job, for he regarded digging ditches for fifty cents a day as slavery. "I can't live on that," (NS.4). It was reported that several hundred Negro employees throughout the city had been dismissed from jobs. (NS. 159)

Most Negro businesses were funeral parlors; white undertakers refused to bother with dead black bodies.(NS. 162)

The quotations (4), (5), and (6) are the examples of the racism in Native Son linguistic expressions which indicate the racism in the employment aspect. The Blacks were often treated unfairly in the employment aspect. To realize the injustice of the treatments, the white race made rules known as Jim Crow Laws (separate but equal). This happened in nearly all aspects of life, for example, education, social assistance, political, and legal protection. It can be described as two races that did not have a relationship, sense of sympathy, and they felt as though from a different planet, so that the black race felt the ' black world' and the ' white world' and even they also believed the ' black god ' and 'white god'.

Related to the above cases, the low jobs which were given to the black race was an implementation of the superiority of the white race. The impact of these strengths led to the dominance against the black race. Therefore, blacks were often treated unfairly, such as discrimination, segregation, and stereotypes. It was very clearly visible during the slavery period, where the relationships between the slaves with the boss were unfriendly. In relation, the white employers often treated their slaves from the black race arbitrarily. To maintain the arbitrariness, the white made a rule known as the Slave Codes. The purposes of Slaves Codes were, firstly to avoid the slaves escape from his or her boss, secondly as a guide to give punishment to slaves escaping, thirdly as the guidelines in giving punishment to a slave who oppose the boss, fourthly as a rule to prohibit the slave gathered-together, and the last is to prohibit the slaves to learn to write and read.

\subsection{Legal Affairs}

The racism ideology also affected the blacks' life in America. It can also be seen in the legal protection for them. As the inferior race, the blacks were often treated unfairly in term of legal affairs. When the blacks broke the rules, they were usually treated differently to the white race. It can be seen from the texts of the racism in Native Son novel. In this case, Richard Wright wanted to show how whites treat blacks in the legal affairs.

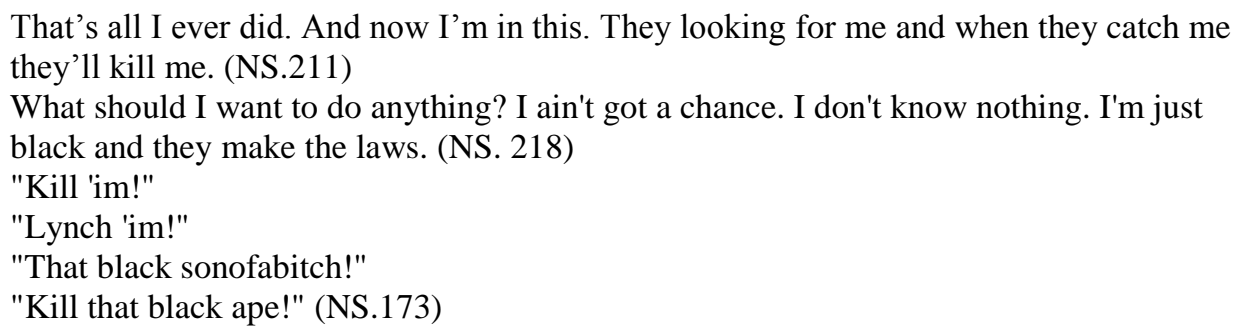

The quoted texts of the Native Son (7), (8), and (9) above show that Richard Wright poses that the Bigger as blacks were treated unfairly due to the reason that they are black and poor. The texts show that the blacks are powerless to fight the legal decision which is received from the court.

The Blacks were also often treated inhumanly in term of legal affairs, for example, in the South United States the blacks were often hanged without passing through the process of law or what is known as lynching. It 
was very clearly seen in the 1930 's, that as many as 154 blacks in the south were hung on wild gallows. At that time, the lynching punishment on blacks was customary in the southern part of United States.

The effects of racism had made the blacks lived in suffering and misery. They did not get a proper justice in the legal affairs. The Declaration of America Independence which included lofty ideals, then was called as the American Creed had not been able to walk properly. The text of the Independence Declaration emphasized individual rights, namely equality in law. In addition, the Declaration of Independence clearly stated to not differentiate the citizens based on skin color.

The rights of justice did not run evenly to all American citizens, especially for the black race. The treatment and society's view of the white race against the black race was still a lot of pros and cons in America. In addressing this issue, the President Lyndon B. Johnson, 24 September 1965, issued Executive Order 11246 as an instruction to the federal contractors to undertake Affirmative Action, about the equal rights of treatment for every citizen and protection against discrimination.

\subsection{Public Facilities Use}

The Racism had led to discrimination, segregation, and prejudice against blacks. As a result of this situation, the blacks' life was miserable. That was because of the assumption of the blacks as racially inferior, while the white race as a superior race, so that the black race was not appropriate to live side by side with the white race. It was very influential on the blacks' life in America, where almost every aspect of life of the black race was always treated differently with the white race. The treatment can be seen from the use of public facilities aspect, where the black race was prohibited from using public facilities belonging to the white race.

The difference of using a common facility between the blacks and whites can be seen in the use of toilets, bus waiting rooms, churches, schools, hospitals, prisons, theaters, hotels, restaurant, barber shop, and a water faucet. Racism raised the separation of the public facilities use among the blacks and whites. A similar different treatment can be seen from the event of the school separation between white and black children at Columbia in 1947.

The separation of public facilities used against blacks can also be seen in the texts of Native Son discourse. Richard Wright illustrated the domination of whites against blacks on the use of public facilities. The dominance of the white race can be seen from the following texts.

(10) There are white schools and black schools, white churches and black churches, white businesses and black businesses, white graveyards and black graveyards, and, for all I know, a white God and a black God.(NS.5)

(11) He lived in the dingy shacks of the white landlords and refused to pay rent. (NS.4)

(12) No white real estate man would rent a flat to a black man other than in the sections where it had been decided that black people might live. (NS.161)

(13) Negro lived upon a common territory, separate from the bulk of the white population. (NS.5)

The texts of (10), (11), (12), and (13) above indicates that racism had made the blacks' life so miserable. The blacks were treated separately by whites. The above texts show as if the relationship of blacks and whites as human beings were from different planets. The impact of this racism was very influential on all aspects of the blacks' life. The injustice of the treatment had made the relationships of whites and blacks were against each other.

The differential treatment against black people can also be seen in the separation of seats on the bus, this incident occurred on December 1, 1955, when Mrs. Rosa Parks who was black descent in Montgomery, chose to sit on the whites' bench. Mrs. Rosa Parks refused to surrender her seat to a white passenger so she was arrested and tried on charges of violating the rules. This event got such attention of the NAACP (National Association for the Advancement of Colored People) and E.D Nixon. The chairman of NAACP local branch asked the blacks to boycott the buses.

The same separation events occurred in common foods. This occurred on February 1, 1960, where four black college students in Greensboro, North Carolina, came and sat down at a lunch spot that was specifically intended for white people, they refused when they were told to go away and still seated in that place. Their action was known as Sit -in [sit strike].

\section{Conclusion}

The results of the analysis of the social dimensions of cognition were named the dimension of analytical discourse. The analytical discourse dimension showed the whole process of production, use and dissemination of Native Son. The Blacks were treated by discrimination, segregation, and separation in education aspect, employment, legal affairs, public facilities use and socio-cultural. In the education aspect, the 
blacks were not allowed in white schools. In the work field, the blacks were given jobs as laborer or inferior. In term of legal affairs, the black race was not given legal protection, threaten injustice toward punishment given, and given a severe punishment when breaking the law. In term of public facilities use, the blacks were not allowed to use the facilities belong to the white race, and were not allowed to be in the same place with the whites.

\section{References}

[1] N. Fairclough, Language and Power (London: Longman, 1989).

[2] N. Fairclough, Discourse and Social Change ( Cambridge: Polity Press, 1992a).

[3] N. Fairclough, Discourse and text: Linguistics and intertextual analysis ( Cambridge : Polity Press, 1992b).

[4] N. Fairclough, Media discourse (London: Edward Arnold, 1995a)

[5] N. Fairclough, Critical Discourse Analysis: The Critical Study of Language (Harlow-Essex:Longman Group Limited,1995b).

[6] N. Fairclough, and Wodak, R. 1997. Critical discourse analysis. In T. A. van Dijk (ed.), Discourse as Social Interaction (London: Sage, 1997) 259-284

[7] N. Fairclough, Analysing discourse: textual analysis for social research. (London: Routledge, 2003)

[8] R. Fowler, 1985. Power. in T.A. van Dijk, (ed.), Handbook of Discourse Analysis: Discourse Analysis in Society (London: Academic Press, 1985) 61-82

[9] R. Fowler, Linguistic Criticism. (Oxford: Oxford University Press, 1986)

[10] M.A.K. Halliday, An Introduction to Functional Grammar (London: Edward Arnold Publishers Ltd, 1985).

[11] McNeilly, M. D. Anderson, and N. B., Armstead, The Perceived Racism Scale: A multidimensional assessment of the experience of White racism among African-Americans. Ethnicity \& Disease, 6, 1996) 154-166

[12] T.A. van Dijk, Communicating Racism: Ethnic Prejudice in Thought and

Talk. (Newbury Park, CA: Sage Publications, Inc, 1987).

[13] T.A. van Dijk, Ideology and Discourse; A Multidisciplinary Introduction (Barcelona: Pompen Praba, 2000).

[14] Richard, Wright, Native Son. (New York : Harper \& Row Publishers, Inc. 1965) 